\title{
Pengaruh Gender Terhadap Keputusan Pembelian Produk Online (Studi Kasus Terhadap Masyarakat Pontianak)
}

\author{
Diana Fitriani*1 \\ ${ }^{1}$ Jurusan Sistem Informasi STMIK Pontianak \\ E-ail: " ${ }^{\text {dianafitriani_8881@ yahoo.com }}$
}

\begin{abstract}
Abstrak
Penerapan pemasaran berbasis online berpengaruh terhadap keputusan pembelian produk dari sisi gender. Sehingga tujuan penelitian untuk mengetahui pengaruh gender terhadap keputusan pembelian produk online pada masyarakat Pontianak. Teknik analisis menggunakan uji statistik Two Way Analysis Of Variance atau lebih dikenal dengan uji ANOVA 2 faktor dengan interaksi secara manual. Teknik pengumpulan data berupa wawancara, observasi dan penyebaran angket.Teknik sampling non probabilitas dengan metode purposive random sampling sebanyak 100 orang responden. Hasil yang diperoleh menyatakan bahwa responden laki-laki dan perempuan masingmasing sebanyak 50\%, usia antara $23-27$ tahun sebanyak 45\%, pendidikan terakhir sarjana sebesar $35 \%$ dengan jenis pekerjaan karyawan swasta sebesar 38\%, pendapatan perbulan 3.000 .000 4.999.000 persentase 54\%. Hasil tersebut menggambarkan bahwa dalam penelitian ini karakteristik pembeli dewasa yang bekerja dengan pendapatan tetapmemiliki kecenderungan melakukan pembelian online. Perempuan memiliki kecenderungan lebih mudah mengambil keputusan pembelian untuk produk yang ditawarkan secara online karena pengaruh perasaan yang feminine dan lebih sensitive ketika melihat iklan pada media online.
\end{abstract}

Kata Kunci-Gender, keputusan pembelian, produk online, ANOVA, deksriptif analisis

\begin{abstract}
The aim of this research is to figure out the effect of gender to the online shopping product decision on Pontianak society. Two or more ways analysis of variance know as ANOVA 2, the technique analysis used which manual simultaneously interaction factor, interview, observation and questionnaire are the technique of data collection implemented. Non probability sampling technique with purposive random sampling method with 100 respondents. The result show that there are 50\% both the female and male respondents, 45\% respondents age range 23-27, 35\% last education as bachelor, $38 \%$ as private staff and 54\% monthly income range 3.000.000., - 4.999.000. The result above indicate hat in this research the adult buyers characteristics, work with fixed income have tendency in shopping products offered online since of the feminine feeling and more sensitive when looking at online media.
\end{abstract}

Keyword-Gender, shopping decision, online product, ANOVA, descriptive analysis

\section{PENDAHULUAN}

Pengaruh era globalisasi serta teknologi yang terus berkembang menciptakan konsep pemasaran menjadi semakin mudah dan praktis. Pemasaran dapat menerapkan teknologi baru yang cepat dan mampu menjangkau konsumen secara global dalam waktu yang relatif singkat dengan spesifikasi biaya pemasaran yang cenderung kecil.Arus penyebaran informasi menjadi bagian yang sangat penting dalam kehidupan bermasyarakat sehingga komunikasi tidak cukup dilakukan hanya dengan berkomunikasi langsung (face to face) [1].

Perkembangan internet sebagai media online di dunia semakin meningkat dari tahun ke tahun. Berdasarkan situs resmi sensus percepatan perkembangan internet dunia menunjukan angka yang sangat signifikan. Hingga tahun 2015 jumlah pengguna internet dunia mencapai 3,2 miliar orang. Ada 
kenaikan 200 juta pengguna dari tahun 2014 lalu. Sesuai dengan data dari kementrian komunikasi dan informatika diperkirakan di Indonesia mencapai 112 juta orang disbanding pada tahun 2014 yang hanya menembus angka 83,7 juta orang. Berdasarkan informasi tersebut dapat diambil kesimpulan bahwa pengguna internet semakin meningkat dari tahun ke tahun sehinga mampu menimbulkan kegairahan produsen untuk memasarkan produknya melalui media online.

Pemasaran produk dengan sistem online secara simultan mempengaruhi proses informasi pemasaran bagi pengguna internet. Informasi yang tersalurkan melalui media ini dianggap mampu untuk mempengaruhi keputusan konsumen terhadap pembelian produk. Pemasaran online juga didukung oleh proses komunikasi yang baik sehingga mampu mendukung keputusan pembelian.Pada umumnya smartphone didasarkan pada sistem operasi tertentu yang memungkinkan pengguna telepon selular untuk mengunduh aplikasi.Cara yang lebih efektif dan efisien ini dianggap berpengaruh tinggi terhadap volume penjualan.

Keputusan pembelian terhadap produk merupakan pernyataan mental konsumen yang merefleksikan rencana pembelian sejumlah produk dengan merek tertentu [2]. Kebutuhan dan keinginan pelanggan sangat berhubungan dengan jenis kelamin ata gender [3].Rangkaian teori diatas menginformasikan bahwa keputusan pembelian terhadap produk juga dipengaruhi oleh jenis kelamin. Pria dan wanita memiliki pola tersendiri pada saat membelanjakan uangnya terhadap produk.Gender merupakan bagian dari segmentasi pasar dari sisi demografi yang menjadi pertimbangan produsen dalam memasarkan produk.Gender merupakan suatu sifat yang melekat pada kaum laki-laki maupun perempuan yang dikontruksi secara sosial maupun kultural [4].

Remaja memiliki kecenderungan inginberpenampilan menarik dan berbeda dari teman sebayanya.Tekanan dari teman sebaya atau biasa disebutpeerpressureyang secara sadar ataupun tidak dapat mempengaruhi perilaku pembelian. Mayoritas remaja adalah kelompok pasar paling potensial karena pola konsumsi yang besar dan beragam.Pada saat melakukan pembelian kelompok ini cenderung saling mempengaruhi sehingga Secara teoritis perilaku pembelian dipengaruhi oleh faktor budaya, sosial dan kepribadian [5].Meurut teori gender yang lain lebih dispesifikasikan bahwa mengungkapkan bahwa gender adalah semua atribut sosial mengenai pria dan wanita, misalnya pria digambarkan memiliki sifat maskulin seperti keras, kuat, rasional dan gagah.Sementara wanita digambarkan memiliki sifat feminine seperti halus, lemah, perasa, sopan, penakut [6].

Perbedaan tersebut di pelajari dari keluarga, tokoh masyarakat, lembaga keagamaan, lembaga pendidikan, lingkungan kerja dan berbagai media masa baik cetak maupun elektronik.Sedangkan seks/kodrat adalah pembagian jenis kelamin manusia berdasarkan fisik biologis yang telah ditentukan oleh Tuhan (kodrati), tidak bisa berubah, tidak bisa dipertukarkan dan bersifat universal.Misalnya wanita mempunyai vagina dan rahim, pria mempunyai penis dan buah zakar.Sampai dengan saat ini kebanyakan masyarakat masih mengartikan Gender sebagai perbedaan jenis kelamin, kondisi tersebut mengakibatkan kesenjangan tanggung jawab dan peran sosial sehingga terjadi ketidakadilan dan ketidaksetaraan antara pria dan wanita dalam masyarakat.

Perusahaan menggunakan teknik pemasaran modern seperti onlinemarketing, viralmarketing, search engine marketing dan e-mailmarketingagar lebih berhasil dalam memenuhi kompetisi [7].Melalui pemasaran online, semakin mudah isi website diakses yang berkaitan dengan produk dan jasa yang ditawarkan maka semakin besar pula kemungkinan bahwa produk dan layanan jasa tersebut untuk dibeli oleh konsumen, karena kecenderungan konsumen yang melakukan gemar melakukan pembelian secara online adalah kelompok konsumen yang memiliki tingkat mobilitas tinggi.Melalui teknik ini dapat dilihat bahwa pertumbuhan teknologi web online telah memicu antusiasme pemasar untuk mengembangkan promosi pelanggan yang lebih responsive. Segala unsur pemasaran termasuk bauran pemasaran produk akan menghasilkan daya tarik tersendiri terhadap konsumen dalam membuat keputusan pembelian.

Kerangka pemikiran yang diuraikan untuk menjelaskan jalan kerja penelitian. Digambarkan pada bagan berikut ini : 
Tabel 1. Operasionalisasi Variabel Penelitian

\begin{tabular}{|c|c|c|}
\hline Variabel & Sub Variabel & Indikator \\
\hline Laki-laki & $\begin{array}{ll}\text { 1. } & \text { Keras } \\
\text { 2. } & \text { Kuat } \\
\text { 3. } & \text { Rasional } \\
\text { 4. } & \text { Gagah }\end{array}$ & $\begin{array}{l}\text { a. Perawakan, tekstur wajah, Sifat } \\
\text { dan kemauan diri } \\
\text { b. Kemampuan, Daya tahan tubuh, } \\
\text { c. Lebih menggunakan kekuatan otak } \\
\text { dalam mestimulus keadaan dan } \\
\text { kebutuhan diri, Tegas } \\
\text { b. Postur tubuh }\end{array}$ \\
\hline Perempuan & $\begin{array}{ll}\text { 1. } & \text { Halus } \\
\text { 2. Lemah } \\
\text { 3. }\end{array}$ & $\begin{array}{ll}\text { a. Tekstur wajah, perawakan, kulit } \\
\text { b. Membutuhkan perlindungan, } \\
\text { Kemampuan, Daya tahan tubuh } \\
\text { c. Mencintai keindahan, kecantikan } \\
\text { d. Sifat yang lebih menggunakan } \\
\text { intuisi dan perasaan dalam } \\
\text { menggambil keputusan, Mudah } \\
\text { jatuh hati, iba dan kasihan, tidak } \\
\text { tega, Perfeksionis }\end{array}$ \\
\hline $\begin{array}{l}\text { Keputusan } \\
\text { Pembelianonline }\end{array}$ & $\begin{array}{l}\text { 1. Harga } \\
\text { 2. Variasi Produk } \\
\text { 3. Kenyamanan } \\
\text { 4. Hiburan }\end{array}$ & $\begin{array}{l}\text { a. Harga yang lebih murah daripada } \\
\text { metode tradisional } \\
\text { b. Jumlah pilihan ragam produk yang } \\
\text { lebih sesuai dengan keinginan } \\
\text { pembeli } \\
\text { c. Keleluasaan terhadap waktu, } \\
\text { lokasi dan proses pembelian lebih } \\
\text { superior } \\
\text { d. Pembelian secara online } \\
\text { seharusnya lebih menyenangkan } \\
\text { daripada alternative lain }\end{array}$ \\
\hline
\end{tabular}

Penelitian pendahulu menyatakan bahwa lingkungan pemasaran online secara positif dan signifikan mempengaruhi perilaku pembelian konsumen online.Lingkungan pemasaran online berpengaruh secara positif dan signifikan terhadap promosi dan promosi berpengaruh secara positif dan signifikan terhadap perilaku pembelian konsumen online [8]. Penelitian lain menyatakan bahwa gender tidak mampu mempengaruhi keputusan pembelian karena pada saat seseorang melakukan pembelian maka faktor emosional dan rasional lebih berpengaruh secara signifikan [9].Sedangkan pendapat lain dalam penelitian serupa menyatakan bahwa kemajuan teknologi informasi yang semakin mendunia menyebabkan perubahan perilaku konsumen dalam membeli produk. Konsumen menuntut layanan pemasaran online melalui internet yang mudah, cepat dan dapat diakses dari mana saja dan kapan saja tanpa terikat jam kerja secara global, pada dasarnya konsumen selalu menginginkan kemudahan bila ingin membeli suatu produk. Dalam upaya meningkatkan volume penjualan maka pengusaha harus dapat menerapkan suatu program periklanan yaitu internet dengan pemasaran online [10].Terdapat sebuah penelitian mengenai gender yang menjabarkan bahwa hasil penelitian menunjukkan bahwa tidak terdapat perbedaan pengetahuan dan pemahaman akan asuransi jiwa pada berbagai usia responden. Gender berpengaruh hanya pada perbedaan pemahaman akan suransi jiwa dan tingkat pendidikan mempengaruhi kesadaran akan asuransi jiwa atau dengan kata lain gender berpengaruh terhadap pemahaman akan asurnasi jiwa tetapi tidak terhadap pengetahuan akan asuransi jiwa [11].

\section{METODE PENELITIAN}

Penelitian berbentuk studi kasus dan metode penelitian bersifat deskriptif analitik.Teknik pengumpulan data yang digunakan berupa wawancara, observasi dan penyebaran angket daftar 
pertanyaan kepada sejumlah responden berdasarkan teori yang menunjang penyelesaian masalah penelitian yaitu mengenai gender terhadap keputusan pembelian produk online. Setiap angket yang disebarkan akan diberikan kepada responden yang pernah melakukan pembelian secara online sedikitnya satu kali. Teknik sampling yang digunakan adalah teknik sample non probabilitas sampling, dengan metode purposive random sampling dimana dinyatakan dalam teknik ini bahwa penentuan sample penelitian dengan beberapa pertimbangan tertentu yang bertujuan agar data yang diperoleh nantinya bias lebih representative [12]. Berdasarkan penjabaran ahli maka peneliti menentukan jumlah responden sebanyak 100 orang dengan mempertimbangkan keterbatasan waktu dalam melakukan penelitian dan keterbatasan dana untuk menunjang proses penyebaran questioner. Pengukuran menggunakan uji statistikTwo Way Analysis Of Variance atau lebih dikenal dengan uji ANOVA2 faktor dengan interaksi secara manual. Dimana pada analisis ini efek interaksi diperoleh setelah setiap kolom dan blok diulang. Interaksi dinyatakan sebagai perkalian baris $\mathrm{X}$ kolom (BK).Menggunakan uji ANOVA2 faktor dengan interaksi secara manual untuk sampel yang sama pada setiap kelompok. Sama diartikan berasal dari kategori yang sama. Fungsinya adalah untuk membandingkan rata-rata kelompok.

Berikut tahapan penyelesaian analisa Two Way Analysis Of Variance (ANOVA) 2 faktor dengan interaksi secara manual (1):

1. Membuat Hipotesis

Ho: $\mu 1=\mu 2$ (artinya: tidak terdapat perbedaan rata-rata yang signifikan)

Ha: $\mu 1 \neq \mu 2$ (artinya: terdapat perbedaan rata-rata yang signifikan)

2. Menyelesaikan perhitungan pada rumus ANOVA berikut:

$J K T=\sum_{i=1}^{r} \sum_{j=1}^{k} \sum_{m=1}^{n} x_{i j m}^{2}-\frac{T^{2}{ }^{* *}}{r k n}$
$J K B=\frac{\sum_{i=1}^{r} T^{2}{ }_{* *}}{k n}-\frac{T^{{ }^{2} * *}}{r k n}$
$J K K=\frac{\sum_{j=1}^{k} T^{2_{*} j^{*}}}{r n}-\frac{T^{{ }^{*} * *}}{r k n}$
$J K[B K]=\frac{\sum_{i=1}^{r} \sum_{j=1}^{k} T^{2}{ }_{i j *}}{n}-\frac{\sum_{i=1}^{r} T^{2}{ }_{i * *}}{k n}-\frac{\sum_{j=1}^{k} T^{2}{ }^{2} j^{*}}{r n}+\frac{T^{2}{ }_{* * *}}{r k n}$
$J K G=J K T-J K B-J K B-J K[B K]$

Dimana:

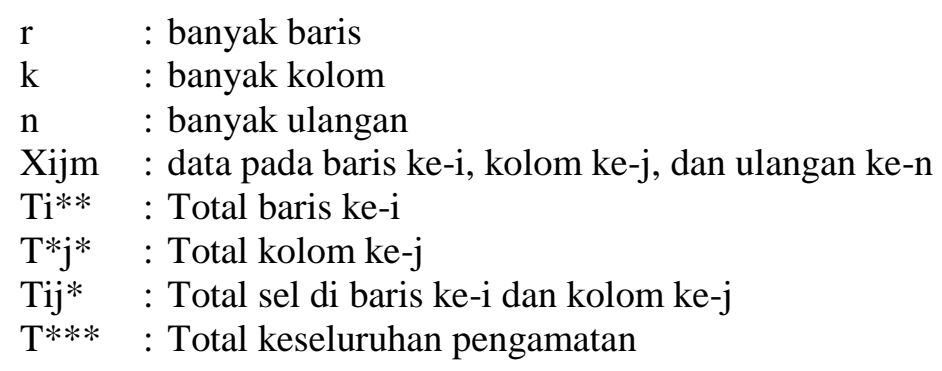


Tabel 2. ANOVA Dua Arah dengan Interaksi

\begin{tabular}{|c|c|c|c|c|c|}
\hline $\begin{array}{l}\text { Sumber } \\
\text { Keragaman } \\
\text { (SK) }\end{array}$ & $\begin{array}{l}\text { Jumlah } \\
\text { Kuadrat } \\
\text { (JK) }\end{array}$ & $\begin{array}{l}\text { derajat } \\
\text { bebas }(\mathrm{db})\end{array}$ & $\begin{array}{l}\text { Kuadrat } \\
\text { Tengah } \\
\text { (KT) }\end{array}$ & F hitung & F tabel \\
\hline $\begin{array}{l}\text { Nilai tengah } \\
\text { Baris }\end{array}$ & JKB & $\begin{array}{l}\mathrm{db} \text { numer } 1 \\
=\mathrm{r}-1\end{array}$ & $\begin{array}{l}\mathrm{KTB}=\underline{\mathrm{JKB}} \\
\mathrm{r}-1\end{array}$ & $\begin{array}{l}\text { F hitung = } \\
\text { KTB } \\
\text { KTG }\end{array}$ & $\begin{array}{l}\alpha= \\
\mathrm{db} \text { numer } 1= \\
\mathrm{db} \text { denum }= \\
\mathrm{f} \text { tabel }=\end{array}$ \\
\hline $\begin{array}{l}\text { Nilai tengah } \\
\text { Kolom }\end{array}$ & JKK & $\begin{array}{l}\text { db numer } 2 \\
=\mathrm{k}-1\end{array}$ & $\begin{array}{l}\mathrm{KTK}=\mathrm{JKK} \\
\mathrm{k}-1\end{array}$ & $\begin{array}{l}\text { F hitung = } \\
\text { KTK } \\
\text { KTG }\end{array}$ & $\begin{array}{l}\alpha= \\
\mathrm{db} \text { numer } 2= \\
\mathrm{db} \text { denum }= \\
\mathrm{f} \text { tabel }=\end{array}$ \\
\hline $\begin{array}{l}\text { Interaksi } \\
{[\mathrm{BK}]}\end{array}$ & $\mathrm{JK}[\mathrm{BK}]$ & $\begin{array}{l}\mathrm{db} \text { numer } 3 \\
=(\mathrm{r}-1)(\mathrm{k}-1)\end{array}$ & $\begin{array}{l}\mathrm{KT}[\mathrm{BK}]= \\
\mathrm{JK}[\mathrm{BK}] \\
(\mathrm{r}-1)(\mathrm{k}-1)\end{array}$ & $\begin{array}{l}\text { F hitung = } \\
\text { KT[BK] } \\
\text { KTG }\end{array}$ & $\begin{array}{l}\alpha= \\
\mathrm{db} \text { numer } 3= \\
\mathrm{db} \text { denum }= \\
\mathrm{f} \text { tabel }=\end{array}$ \\
\hline Galat & JKG & $\begin{array}{l}\text { db denumer } \\
=\mathrm{r} \cdot \mathrm{k}(\mathrm{n}-1)\end{array}$ & $\begin{array}{l}\mathrm{KTG}=\mathrm{JKG} \\
\text { r.k(n-1) }\end{array}$ & & \\
\hline Total & JKT & $($ r.k.n) -1 & & & \\
\hline
\end{tabular}

3. Membandingkan Nilai $F$ hitung dengan $F$ tabel

Jika $\mathrm{f}_{\text {hitung }}<\mathrm{f}_{\text {tabel }}$ maka Ha ditolak dan Ho diterima

Jika $\mathrm{f}_{\text {hitung }}>\mathrm{f}_{\text {tabel }}$ maka Ha diterima dan Ho ditolak

4. Membuat Kesimpulan. Dimana kesimpulan yang akan diambil sesuai dengan kenyataan yang terjadi dilapangan. Berdasarkan pada kuesioner yang disebarkan untuk keseluruhan responden yang ditabulasi menggunakan pengujian Anova.

Data yang diperoleh dengan mentabulasi jawaban responden dengan skala likert.Skala likert umumnya digunakan untuk menilai pendapat atau persepsi responden mengenai perilaku dan fenomena sosial dalam penelitian. Kuesioner diajukan dengan menentukan skala lima tingkat yaitu, 1 = sangat tidak setuju, 2 = tidak setuju, 3 = kurang setuju, $4=$ setuju, $5=$ sangat setuju [13].

\section{HASIL DAN PEMBAHASAN}

Hasil yang diperoleh berdasarkan data kuesioner yang disebarkan kepada responden sebanyak 100 orang dengan karakteristik responden dilihat dari kriteria jenis kelamin, usia, pendidikan, pekerjaan dan pendapatan. Berdasarkan lima karakteristik responden dikondisikan untuk keseimbangan jumlah responden laki-laki dan perempuan untuk menghindari kecenderungan secara kasat mata. Berikut ini tabel yang menjelaskan dengan lebih rinci lima karakteristik tersebut :

Tabel 3. Karakteristik Responden

\begin{tabular}{|l|l|c|c|}
\hline \multirow{2}{*}{ No } & \multicolumn{1}{|c|}{ Karakteristik responden } & Jumlah responden & Presentase (\%) \\
\hline 1 & Jenis Kelamin & & \\
& 1. Laki-laki & 50 & $50 \%$ \\
& 2. Perempuan & 50 & $50 \%$ \\
\hline & Jumlah & 100 & $100 \%$ \\
\hline 2 & Usia (Tahun) & 15 & $15 \%$ \\
& $1 . \quad 18-22$ & 45 & $45 \%$ \\
& $2.23-27$ & 25 & $25 \%$ \\
& $3.28-32$ & 15 & $15 \%$ \\
\hline
\end{tabular}




\begin{tabular}{|l|l|c|c|}
\hline & Jumlah & 100 & $100 \%$ \\
\hline 3 & Pendidikan & & \\
& 1. SLTA & 30 & $30 \%$ \\
& 2. Diploma & 12 & $12 \%$ \\
& 3. Sarjana & 35 & $35 \%$ \\
& 4. Pasca sarjana & 23 & $23 \%$ \\
\hline & Jumlah & 100 & $100 \%$ \\
\hline 4 & Pekerjaan & 28 & $28 \%$ \\
& 1. Pelajar/mahasiswa & 23 & $23 \%$ \\
& 2. PNS/BUMN & 38 & $38 \%$ \\
& 3. Swasta & 11 & $11 \%$ \\
\hline \multirow{2}{*}{5} & Jumlah & 100 & $100 \%$ \\
& Pendapatan (IDR/Bulan) & 18 & $18 \%$ \\
& 1. $1.000 .000-2.999 .000$ & 54 & $54 \%$ \\
& 2. 3.000.000-4.999.000 & 23 & $23 \%$ \\
& 3. $5.000 .000-6.999 .000$ & 5 & $5 \%$ \\
\hline & 4. $>7.000 .000$ & 100 & $100 \%$ \\
\hline
\end{tabular}

Berdasarkan karakteristik pada tabel 3 dirincikan bahwa jumlah responden laki-laki dan perempuan masing-masing sebanyak 50\%, usia antara $23-27$ tahun sebanyak $45 \%$, pendidikan terakhir para responden lebih banyak pada pilihan sarjana sebesar 35\% dengan jenis pekerjaan karyawan swasta sebesar 38\% dan jumlah pendapatan perbulan berkisar antara 3.000.000 - 4.999.000 dengan jumlah persentase sebesar 54\%.Hasil tersebut menggambarkan bahwa dalam penelitian ini berkarakteristik terhadap pembeli dewasa yang bekerja dengan pendapatan tetapsehingga memiliki kecenderungan untuk melakukan pembelian online.

Penelitian ini juga dianalisis secara kualitatif dengan analisis statistikTwo Way Analysis of Variance (ANOVA) dengan interaksi secara manual. Berikut ini penyelesaian dengan ANOVA 2 faktor :

1. Membuat Hipotesis

Ho: $\mu 1=\mu 2$ (artinya: tidak terdapat perbedaan rata-rata yang signifikan antara gender pria dan wanita terhadap keputusan pembelian online)

Ha: $\mu 1 \neq \mu 2$ (artinya: terdapat perbedaan rata-rata yang signifikan antara gender pria dan wanita terhadap keputusan pembelian online) 


$$
\begin{aligned}
& J K T=\left(\begin{array}{l}
3,83^{2}+3,37^{2}+3,32^{2}+4,02^{2}+3,32^{2}+3,66^{2}+3,08^{2}+3,01^{2}+2,98^{2}+3,47^{2}+ \\
3,35^{2}+3,45^{2}+3,8^{2}+3,51^{2}+3,21^{2}+3,91^{2}+3,59^{2}+3,7^{2}+3,31^{2}+3,46^{2}+ \\
2,73^{2}+3,67^{2}+3,61^{2}+3,46^{2}+3,35^{2}+3,24^{2}+2,85^{2}+3,47^{2}+3,49^{2}+3,13^{2}+ \\
3,66^{2}+3,52^{2}+3,19^{2}+3,71^{2}+3,43^{2}+3,46
\end{array}\right)-\frac{123,32^{2}}{6 \times 2 \times 3} \\
& J K T=425,33-2 \frac{15207,80}{36}=2,89 \\
& J K B=\frac{21,5^{2}+19,34^{2}+21,72^{2}+20,24^{2}+19,53^{2}+20,97^{2}}{2 \times 3}-\frac{123,32^{2}}{6 \times 2 \times 3} \\
& J K B=\frac{2539,72}{6}-\frac{15207,80}{36}=0,85 \\
& J K K=\frac{59,42^{2}+63,9^{2}}{6 \times 3}-\frac{123,32^{2}}{6 \times 2 \times 3} \\
& J K K=\frac{7613,95}{18}-422,44=0,56 \\
& J K[B K]=\frac{10,52^{2}+9,07^{2}+10,52^{2}+9,5^{2}+9,44^{2}+10,37^{2}+11^{2}+10,27^{2}+11,2^{2}+10,74^{2}+10,09^{2}+10,6^{2}}{3}- \\
& \frac{21,5^{2}+19,34^{2}+21,72^{2}+20,24^{2}+19,53^{2}+20,97^{2}}{2 \times 3}-\frac{59,42^{2}+63,9^{2}}{6 \times 3}+\frac{123,32^{2}}{6 \times 2 \times 3} \\
& J K[B K]=\frac{1271,94}{3}-\frac{2539,72}{6}-\frac{7613,95}{18}+\frac{15207,80}{36}=0,14 \\
& J K G=2,89-0,85-0,56-0,14=1,34
\end{aligned}
$$

\begin{tabular}{|c|c|c|c|c|c|}
\hline $\begin{array}{l}\text { Sumber } \\
\text { Keragaman } \\
\text { (SK) }\end{array}$ & $\begin{array}{c}\text { Jumlah } \\
\text { Kuadrat (JK) }\end{array}$ & $\begin{array}{l}\text { derajat bebas } \\
\text { (db) }\end{array}$ & $\begin{array}{c}\text { Kuadrat } \\
\text { Tengah }(\mathrm{KT})\end{array}$ & F hitung & $\mathrm{F}$ tabel \\
\hline $\begin{array}{l}\text { Nilai tengah } \\
\text { Baris }\end{array}$ & $\begin{array}{l}\mathrm{JKB}= \\
0,85\end{array}$ & $\begin{array}{l}\text { db numer } 1 \\
=r-1 \\
=6-1=5\end{array}$ & $\begin{array}{l}\mathrm{KTB}=\underline{\mathrm{JKB}} \\
\mathrm{r}-1 \\
\mathrm{KTB}=0,17\end{array}$ & $\begin{array}{l}\text { F hitung } \\
=\underline{\text { KTB }} \\
\text { KTG } \\
=3,036 \mathrm{~ns}\end{array}$ & $\begin{array}{l}\alpha=5 \% \\
\mathrm{db} \text { numer } 1=5 \\
\mathrm{db} \text { denum }=24 \\
\mathrm{f} \text { tabel }=2,621\end{array}$ \\
\hline $\begin{array}{l}\text { Nilai tengah } \\
\text { Kolom }\end{array}$ & $\begin{array}{l}\mathrm{JKK}= \\
0,56\end{array}$ & $\begin{array}{l}\text { db numer } 2 \\
=\mathrm{k}-1 \\
=2-1=1\end{array}$ & $\begin{aligned} \mathrm{KTK} & =\underline{\mathrm{JKK}} \\
\mathrm{k}-1 & \\
\mathrm{KTK} & =0,56\end{aligned}$ & $\begin{array}{l}\text { F hitung } \\
=\underline{\text { KTK }} \\
\text { KTG } \\
=10 \mathrm{~ns}\end{array}$ & $\begin{array}{l}\alpha=5 \% \\
\mathrm{db} \text { numer } 2=1 \\
\mathrm{db} \text { denum }=24 \\
\mathrm{f} \text { tabel }=4,260\end{array}$ \\
\hline $\begin{array}{l}\text { Interaksi } \\
{[\mathrm{BK}]}\end{array}$ & $\mathrm{JK}[\mathrm{BK}]=0,14$ & $\begin{array}{l}\text { db numer } 3 \\
=(\mathrm{r}-1)(\mathrm{k}-1) \\
=5 \times 1=5\end{array}$ & $\begin{array}{l}\mathrm{KT}[\mathrm{BK}]= \\
\mathrm{JK}[\mathrm{BK}] \\
(\mathrm{r}-1)(\mathrm{k}-1) \\
\\
\mathrm{KT}[\mathrm{BK}]= \\
0,028\end{array}$ & $\begin{array}{l}\text { F hitung } \\
=\frac{\mathrm{KT}[\mathrm{BK}]}{\mathrm{KTG}} \\
=0,5 *\end{array}$ & $\begin{array}{l}\alpha=5 \% \\
\mathrm{db} \text { numer } 3=5 \\
\mathrm{db} \text { denum }=24 \\
\mathrm{f} \text { tabel }=2,621\end{array}$ \\
\hline Galat & $\mathrm{JKG}=1,34$ & $\mathrm{db}$ denumer $=$ & KTG $=$ & & \\
\hline
\end{tabular}

2. Menyelesaikan Perhitungan pada Rumus ANOVA berikut:

Tabel 4. Anova Dua Arah dengan Interaksi 


\begin{tabular}{|c|c|c|c|}
\hline & & $\begin{array}{l}\text { r.k(n-1) } \\
=6 \times 2(3-1) \\
=24\end{array}$ & $\begin{array}{l}\frac{\mathrm{JKG}}{\mathrm{r} \cdot \mathrm{k}(\mathrm{n}-1)} \\
\mathrm{KTG}=0,056\end{array}$ \\
\hline Total & $\mathrm{JKT}=2,89$ & $\begin{array}{l}=(\text { r.k.n })-1 \\
=(6 \times 2 \times 3)-1 \\
=35\end{array}$ & \\
\hline
\end{tabular}

Keterangan : Tanda ns (Ho ditolak)

Tanda $*$ (Ho diterima)

3. Penjelasan:

Secara Baris

Secara Kolom

: $\quad$ F hitung $>$ F tabel (Ho ditolak)

$\mathrm{F}$ hitung $>\mathrm{F}$ tabel (Ho ditolak)

Secara Interaksi $[\mathrm{BK}] \quad$ : $F$ hitung $<\mathrm{F}$ tabel $\quad$ (Ho diterima)

Dari hasil perhitungan tersebut, menunjukkan bahwa secara interaksi atau bersama-sama rata-rata keputusan pembelian online dapat dikatakan sama pada gender pria maupun wanita. Sedangkan pada baris (keputusan pembelionline) dan kolom (gender) terjadi perbedaan yang signifikan mengenai keputusan pembelian online antara pria dan wanita.Dijelaskan dengan perhitungan yang terdapat pada nilai distribusi $\mathrm{F}$ (Fhitung) berdasarkan perbandingan varienceantar kelompok dan variance dalam kelompok.F hitung ada tiga karena hipotesis ada tiga sehingga diperoleh nilai $\mathrm{F}$ hitung secara baris sebesar 10 sedangkan $\mathrm{F}$ tabel sebesar 4.260 yang berarti Ho ditolak. Sejalan dengan $\mathrm{F}$ hitung secara kolom diperoleh nilai sebesar 3.036 sedangkan $\mathrm{F}$ tabel sebesar 2.621 yang berarti Ho ditolak. Sedangkan untuk F hitung secara interaksi diperoleh nilai sebesar 0,5 sedangkan $\mathrm{F}$ tabel sebesar 2.621 yang berarti Ho diterima.

\section{KESIMPULAN}

Penelitian pengukuran pengaruh gender terhadap keputusan pembelian onlinedengan metode analisis statistik Two Way Analysis Of Variance (ANOVA) 2 faktor. Penyebaran kuesioner dengan skala likert sebagai alat ukur utama dalam menentukan keseluruhan nilai atas jawaban responden yang berjumlah 100 orang. Kesimpulan berdasarkan perhitungan menunjukkan bahwa secara interaksi atau bersama-sama rata-rata perilaku konsumen dalam melakukan pembelian online adalah sama pada gender lai-laki maupun perempuan. Dengan penjelasan bahwa apabila keputusan pembelian online dilakukan dalam waktu yang bersama-sama pada konteks yang samapula maka kedua hal tersebut bisa saling mendukung dalam melakukan interaksi dalam menggambil keputusan pembelian. Sedangkan pada baris keputusan pembelian dan kolom gender terjadi perbedaan yang signifikan mengenai keputusan pembelian online antara laki-laki dan perempuan. Kesimpulan akhirnya adalah bahwa perempuan memiliki kecenderungan yang lebih banyak untuk melakukan keputusan pembelian produk secara online.Berdasarkan hasil observasi dilapangan informasi yang terkumpul dapat disimpulkan bahwa perempuan memiliki kecenderungan lebih mudah mengambil keputusan pembelian untuk produk yang ditawarkan secara onlinekarena pengaruh perasaan yang feminine dan lebih sensitive ketika melihat iklan pada media online.

\section{SARAN}

Berdasarkan semua hasil yang telah dilakukan disarankan kepada pihak online shop sebagai suatu sarana berbelanja agar lebih memperkuat layanan dan terus meningkatkan promosi produk yang berkesinambungan dengan memperhatikan seluruh aspek yang mampu untuk meningkatkan antusiasme konsumen dalam menaruh perhatian untuk memiliki hasrat yang dalam sebelum pada akhirnya mengambil keputusan untuk melakukan pembelian produk. Tampilan yang menarik mata dan keterangan yang memuaskan konsumen dalam memilih produk harus menjadi bagian yang diprioritaskan dalam menyampaikan informasi produk secara online. Informasi secara detail yang menyertai foto dengan keterangan yang menggambarkan penjelasan secara keseluruhan dapat 
disesuaikan dengan kebutuhan konsumen untuk menunjang keputusan pembelian masih harus jelas dan lengkap sesuai dengan kualitas produk yang sesungguhnya. Karena pada dasarnya setiap orang menyukai keindahan, kerapian dan informasi yang baik dan detail.Berguna untuk menyamankan persepsi antar penjual dan pembeli.Persamaan persepsi ini menunjang konsumen untuk melakukan pembelian kembali pada online shop tersebut dilain kesempatan.

\section{UCAPAN TERIMA KASIH}

Terima kasih kepada pihak-pihak yang telah membantu sehingga penelitian ini dapat diselesaikan dengan baik serta dapat di implementasikan.

\section{DAFTAR PUSTAKA}

[1] Wirawan, Noviana., 2011, Analisa Sistem Keamanan Terhadap Serangan Virus Pada Smartphone Berbasis Android dan Symbian OS (Studi Kasus Pada Samsung Galaxy 550 Dan Nokia E63), Jurnal Teknik Informatika.

[2] Hatane, Samuel., Annetteveronika Kosasih., 2007, Perilaku dan Keputusan KonsumenRestoran Melalui Stimulus 50\% Discount Di Mall Surabaya.Jurnal Manajemen Pemasaran.

[3] Kotler,Philip., Kevin, L. Keller., 2009, Manajemen Pemasaran, Edisi 13, Jilid 1, Erlangga.

[4] Fakih, Mansour., 2008, Analisis Gender dan Transformasi Sosial, Insistpress.

[5] Yohanes., 2008, Keputusan Membeli Secara Online dan Faktor-faktor Yang Mempengaruhi,JurnalTeknologi Informasi, 8(2) : Pp : 140-246

[6] Sadli, Saparinah.,2010, Pemikiran Tentang Kajian Perempuan. PT Kompas Media Nusantara, Jakarta.

[7] Gautman, R. K., 2012,Internet Marketing Usage By Small Indian Entrepreneurs: An Exploration Study Of Punjab. International Review Of Management And Marketing, 2 (1) : 4351.

[8] Partha, Cokorda GG., Sukawati, TG Raka., 2016, Peran Promosi Dalam Memediasi Lingkungan Pemasaran Online Terhadap Perilaku Pembelian Online (Studi Di Kota Denpasar), E-Jurnal Manajemen Unud, Vol. 5, No. 5, Hal 3053-3079.

[9] Calistas, IGA Audy.,2015,Pengaruh Motivasi Rasional, Motivasi Emosional Dan Harga Diri Terhadap Keputusan Pembelian Smartphone Pada Mahasiswa Universitas Udayana Dimoderasi Oleh Gender, E-Jurnal Manajemen Unud Vol. 4, No. 5, Hal 1322-1335.

[10] Wandanaya,Anita B.,2012, Pengaruh Pemasaran Online Terhadap Keputusan PembelianProduk, Vol.5, No. 2, Hal 174-185.

[11] Hermawati, S. 2013. Pengaruh Gender, Tingkat Pendidikan Dan Usia Terhadapat Kesadaran Berasuransi pada Masyarakat Indonesia. Jurnal Asuransi dan Manajemen Risiko, 1(1).

[12] Sugiyono.,2010, Statistik Untuk Penelitian, Bandung, Alfabeta.

[13] Umar., 2013, Metode Riset Bisnis, Jakarta, PT. Gramedia Pustaka Utama. 